\title{
DIRECTIVE MANAGEMENT AND PEDAGOGICAL INNOVATION MODEL FOR PUBLIC UNIVERSITIES
}

Miriam Viviana Ñañez Silva

Universidad Nacional de Cañete - UNDG, Lima, (Perú). E-mail: mnanez@undc.edu.pe ORCID: https://orcid.org/0000-0001-8929-2916

Rosario Blanca Pariona Luque

Universidad Nacional Autónoma de Huanta - UNAH, Ayacucho, (Perú). E-mail: rpariona@unah.edu.pe ORCID: https://orcid.org/0000-0002-8468-7801

Julio Cesar Quispe Galderón

Universidad Nacional de Cañete - UNDC, Lima, (Perú). E-mail: jquispe@undc.edu.pe ORCID: https://orcid.org/0000-0003-2352-5670

Hernan Diaz Rengifo

Universidad Nacional San Luis Gonzaga - UNICA, Ica, (Perú). E-mail: hernan.diaz@unica.edu.pe ORCID: https://orcid.org/0000-0003-1099-1074

Gitación sugerida Suggested citation

Ñañez, M. V., Pariona, R. B., Quispe, J. C., y Diaz, H. (2021). Directive management and pedagogical innovation model for public universities. 3C Empresa. Investigación y pensamiento crítico. Edición Especial Tourism and University: Backbone of Peruvian Economy, 33-45. https://doi.org/10.17993/3cemp.2021. specialissue 1.33-45 


\section{ABSTRACT}

To achieve success and achieve quality learning, the integral functioning of the processes of educational institutions must be developed, organized and evaluated, but there is a significant gap where the directive management is out of focus with the fulfillment of objectives and lack of pedagogical innovation in their Teaching and learning processes. Therefore, this research presents a model of directive management and pedagogical innovation for public universities in the Province of Cañete. The research approach is quantitative with a nonexperimental, correlational and cross-sectional design, the technique used was the survey which was applied to 20 university professors with respect to the managerial management variable with its indicators promoting pedagogical changes, decision making, teacher communication and the dependent variable pedagogical innovation with its indicators teacher training and technological perspective, with a Cronbach's alpha coefficient of 0.909 . The results indicate that $40 \%$ of teachers show regular pedagogical changes, $45 \%$ indicate that the use of technology is low in their learning session to achieve competencies and $60 \%$ express that the benefit of their decisions for their students is regular. These results reflect that the public universities of Cañete must implement a managerial management model and technological innovation to improve educational quality based on institutional development, the fulfillment of objectives, be at the forefront of social progress and favor teaching and learning processes.

\section{KEYWORDS}

Directive Management, Pedagogical Innovation, Model, Public Universities, Cañete. 


\section{INTRODUCTION}

In recent years, the demand for teaching directors to be in line with the imposition of globalization generates many problems to be able to manage their institutions, including school violence, advances in society and the increase in technology (Reynoso, 2018). For this reason, teaching directors are in charge of meeting the multiple challenges and demands of society to achieve institutional development. The directive management is of great importance in the educational institutions since it allows to improve collectively from the work in conjunction with the directive teams that must ensure the fulfillment of the mission, vision and objectives of the institution (López, García \& Martínez, 2019).

Pedagogical leadership is an essential aspect in directive processes and in the activities that are carried out daily in institutions, in the same way, pedagogical innovation is a process in which situations are transformed in a meaningful, pertinent and deliberate way by other different situations. that are functional, aimed at improving educational quality and equity, adapting to the introduction of new innovative methods (Medina, 2019). Innovation is a process that requires reflection and participation of the directors of the institutions, in which it is defined, built and socially participates. In teaching, innovation serves as a transformation generating knowledge and new technologies; involving changes with new methodologies, teaching techniques to develop knowledge and meaningful learning in students (Mejía, 2018). Said meaningful learning implies the use of strategies, teaching resources and methods, thus achieving institutional development. Innovation in teacher training must be continuous and must point towards the capacities and virtues of teachers so that they perceive the necessary changes in organizations (Martínez \& Ibarra, 2017).

Education implies the appropriation and application of changes for them it is necessary to do research that promotes teaching techniques and methodologies developing the knowledge of students. In the province of Cañete, directive management is a complex function since it requires institutional development, the fulfillment of objectives and being at the forefront of social progress. Optimization is required the organization of institutions and enhance their teaching and learning processes (Rodríguez, 2018).

The lack of adequate directive management generates that the institutions do not have a good administration of their resources and therefore the institutional objectives and goals 
cannot be met, damaging the teaching and learning of students. Executive management and pedagogical innovation seek to guide the management team to reestablish institutional processes in search of continuous improvement. For this reason, the objective of the research is to propose a model of directive management and pedagogical innovation in public universities of Cañete that improve institutional results, teaching processes through pedagogical changes, decision-making for the benefit of students; For this, the teacher must train constantly and permanently, as well as be at the forefront of technological advances to achieve an education for all.

\section{THEORETICAL BASES}

\subsection{DIRECTIVE MANAGEMENT}

Focuses on the strategic direction, the institutional culture, the organizational climate, the relations with the environment and the governance of the educational institution. In this way, the highest authority or rector and the management team organize, develop and evaluate the general operation of the institution. All organizations currently require leadership, which is an essential characteristic for management teams who must combine leadership within their management processes in which competence, skill and attitude serve to develop the ability to direct, motivate and influence the work team, meeting shared goals and continually improving (Miranda, 2016). Directive management in educational organizations implies defining the scope of management and administration based on the understandings, perspectives and experiences of the directive personnel (Reynoso, 2018). In this way, to manage in an educational institution, administrative actions must be carried out, but also train and train the educational team representing its nature and responsibility in society.

\subsection{PROMOTION OF PEDAGOGICAL CHANGES}

The promotion of pedagogical changes in the direction and organization of the teaching process has made them become transmitters of information to leaders of the same; the teaching authority that imposed inferiority on students has to be changed by the cooperation between students and teachers so that communication skills can be developed with students, interaction and direction of their activities, which improves the role of teacher leader (Miña 
et al., 2018). To develop the change in pedagogy, teachers are needed who are prepared and updated with capacities to respond to the demands in their professional performance, who are willing and committed to actively participate in the changes, to achieve their selfimprovement and improve educational quality (Aguiar et al., 2016). Management, attitude and teacher training are related to change, new learning styles and pedagogical approaches change the educational mechanism.

\subsection{THE DECISION-MAKING PROCESS}

Decision-making process in institutions allows defining problems, collecting data, generating alternatives and selecting courses of action (Bustos \& Vicuña, 2016). Teachers constantly make decisions to conceive, apply and design assessment instruments in the classroom that improve teaching. Teachers must also make decisions for the benefit of students by creating assessment strategies to improve their academic performance (Gallardo et al., 2012).

For this reason, it is essential that the teacher work to strengthen their evaluation skills specifically in the formative type, which will allow them to closely monitor the student's teaching and learning process, achieving the proposed goals and objectives. Another aspect to achieve good directive management is teacher communication, which is the basis for learning, being a tool that the teacher must handle in order to achieve good relationships with students (Abraham, Donoso \& Guzmán, 2017). The relationship between the student and the teacher strengthens the teaching and learning processes; Through dialogue that transmits, transfers and builds knowledge, forming independence, which allows developing the reflective and critical sense, skills and abilities to develop in society (Escobar, 2015).

\subsection{PEDAGOGICAL INNOVATION}

Refers to a systemic and complex process that helps to reflect and intervene in the learning process of students (González \& Cruzat, 2019). This educational innovation promotes pedagogical development so that an educational institution faces the rapid obsolescence of knowledge, constant transformation of society and problems associated with higher university education. Another function of pedagogical innovation is to solve learning problems by seeking new ideas, proposals and contributions to create a change in the context and in teaching practice, being essential for the organizational culture and the 
improvement of educational quality (Macanchí, Orozco \& Campoverde, 2020); being an alternative of great value to make decisions about educational, pedagogical and didactic changes.

\subsection{TEACHER TRAINING}

Has to be continuous and permanent so that there is truly a change in society; it is necessary for development and social transformation that require the teacher to be an active agent of learning to transform social reality (Nieva \& Orietta, 2016). The permanent training of teachers is understood as an updating process that makes it possible to carry out pedagogical and professional practices in a meaningful, appropriate and pertinent way in social contexts and populations that the teacher serves. Therefore, stimulating professional updating and constant training allows responding to the socioeconomic development of a country and its specific environment (Vergara et al., 2004). Said teacher training must be comprehensive, adopting technology as a tool to teach and generate new knowledge in the student, in addition to training teachers with constructivist, reflective and evaluative practices. Technology in society presents limitations, including technical, security, cultural and economic problems, but this should not limit teacher training that seeks new learning alternatives with technological resources (Hernández, Orrego \& Quiñones, 2018).

Another aspect to improve pedagogical innovation is the technological perspective that takes advantage of technology to contribute to the achievement of an education for all. The trend in the use of technology has been aimed at developing models of distance education and incorporating new innovative educational practices in teachers and students; Teachers must have technical knowledge in technology through a positive attitude towards these resources that are necessary for effective learning (Pedraza et al., 2013). Therefore, teachers must develop skills to incorporate these new technologies since the quality of learning and teaching of students is largely related to teacher training. Among the educational changes generated by technology is the use of platforms where classes can be offered to many users, which benefits students who due to their geographical location are far from being able to carry out face-to-face training and those who do not have time and prefer to learn from home in their spare time (Buzón-García, 2005). 


\section{METHOD}

The present research is of a quantitative approach with a non-experimental, correlational and cross-sectional design, it is made up of 100 teachers from public universities in the province of Cañete. The sample consisted of 20 teachers, the instrument used was a questionnaire about the independent variable directive management with the indicators promoting pedagogical changes, decision-making and teacher communication with a total of 12 questions and the dependent variable pedagogical innovation that contains the indicators teacher training and technological perspective with a total of 8 questions. The Likert scale was used, validated by the judgment of experts with a reliable questionnaire with a Cronbach's alpha coefficient of 0.909 .

\section{RESULTS}

The questionnaire was applied to a total of 20 teachers from public universities in Cañete, based on this, the following results could be obtained and analyzed:

Table 1 shows the results of the indicator promoting pedagogical changes regarding the directive management variable, $40 \%$ of teachers indicate that the pedagogical changes they carry out are regular, while 35\% consider it high and $25 \%$ low.

Table 1. Do you make pedagogical changes by putting your personal experience into practice professional?

\begin{tabular}{|c|c|c|}
\hline Levels & Frequency & Percentage \\
\hline Low & 5 & $25 \%$ \\
\hline Regular & 8 & $40 \%$ \\
\hline High & 7 & $35 \%$ \\
\hline Total & 20 & $100 \%$ \\
\hline
\end{tabular}

Source: own elaboration.

Table 2 indicates the results of the decision-making indicator about the same variable, $60 \%$ express that the benefit of their decisions for their students is regular, while $40 \%$ indicate that it is high.

Table 2. Do you make decisions for the benefit of your students considering their needs?

\begin{tabular}{|c|c|c|}
\hline Levels & Frequency & Percentage \\
\hline Low & 0 & $0 \%$ \\
\hline Regular & 12 & $60 \%$ \\
\hline
\end{tabular}




\begin{tabular}{|c|c|c|}
\hline Levels & Frequency & Percentage \\
\hline High & 8 & $40 \%$ \\
\hline Total & 20 & $100 \%$ \\
\hline
\end{tabular}

Source: own elaboration.

Table 3 indicates the results of the teacher communication indicator on the same variable. $80 \%$ indicate that the strengthening of the teaching and learning process thanks to communication is high and $20 \%$ consider it regular.

Table 3. Do you consider that teacher communication strengthens the teaching and learning process in students?

\begin{tabular}{|c|c|c|}
\hline Levels & Frequency & Percentage \\
\hline Low & 0 & $0 \%$ \\
\hline Regular & 4 & $20 \%$ \\
\hline High & 16 & $80 \%$ \\
\hline Total & 20 & $100 \%$ \\
\hline
\end{tabular}

Source: own elaboration.

Table 4 indicates the results of the teacher training indicator on the pedagogical innovation variable. $80 \%$ indicate that their participation in updating workshops and trainings is regular and $20 \%$ indicate that it is high.

Table 4. Do you participate in the refresher training or workshops proposed by your university?

\begin{tabular}{|c|c|c|}
\hline Levels & Frequency & Percentage \\
\hline Low & 0 & $0 \%$ \\
\hline Regular & 16 & $80 \%$ \\
\hline High & 4 & $20 \%$ \\
\hline Total & 20 & $100 \%$ \\
\hline
\end{tabular}

Source: own elaboration.

Table 5 indicates the results of the technological perspective indicator on the dependent variable. $45 \%$ indicate that the use of technology in their learning session to achieve competencies is low, while $35 \%$ consider it regular and $20 \%$ high.

Table 5. Do the activities planned in your learning session promote the use of technology to achieve competencies?

\begin{tabular}{|c|c|c|}
\hline Levels & Frequency & Percentage \\
\hline Low & 9 & $45 \%$ \\
\hline Regular & 7 & $35 \%$ \\
\hline High & 4 & $20 \%$ \\
\hline Total & 20 & $100 \%$ \\
\hline
\end{tabular}

Source: own elaboration. 


\section{PROPOSAL}

Based on the results of the survey, the following model of directive management and pedagogical innovation in public universities is proposed, which helps us to evaluate the current state of the national universities of Cañete and then apply the model and obtain ideal results.

DIRECTIVE MANAGEMENT AND PEDAGOGICAL INNOVATION MODEL. FOR PUBLIC UNIVERSITIES OF CAÑETE

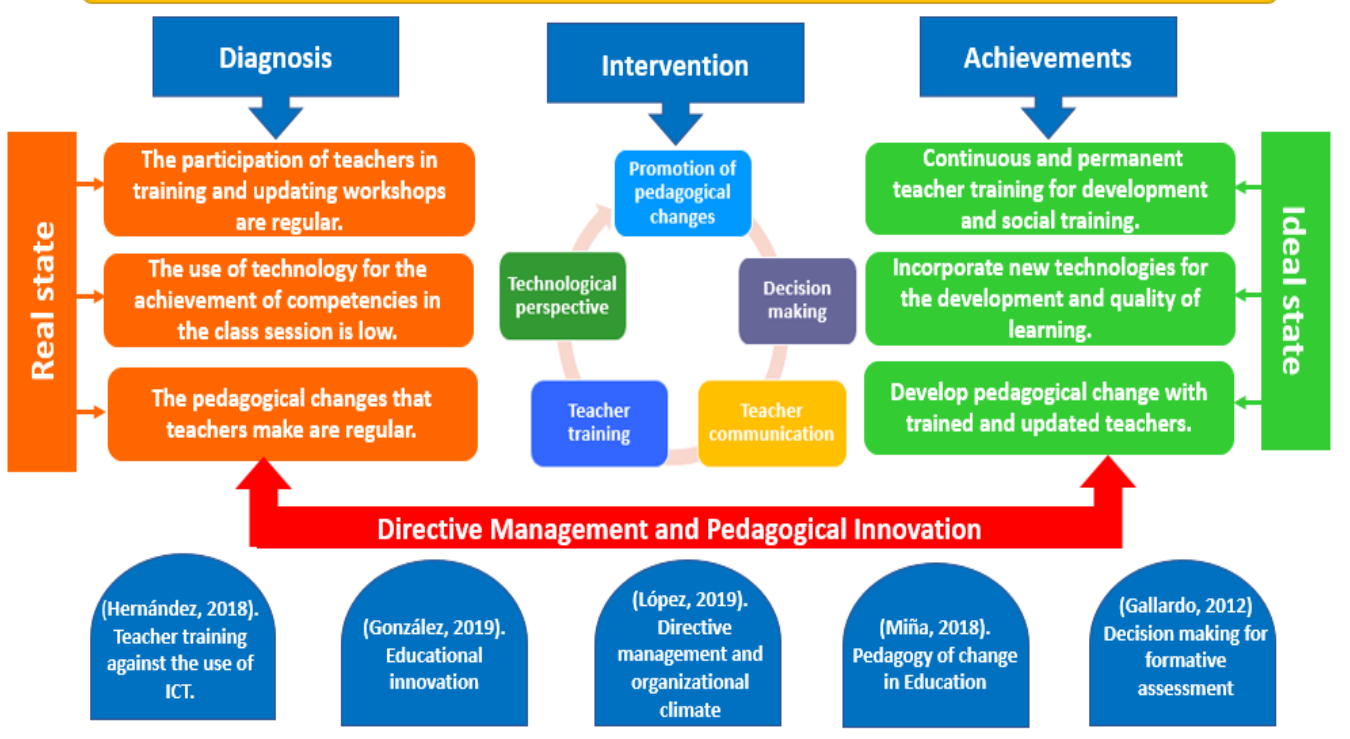

Figure 1: Directive management model and pedagogical innovation.

Source: own elaboration.

\section{DISCUSSION}

This research proposes the application of a model of directive management and pedagogical innovation in teachers of public universities in Cañete.

In Table $1,40 \%$ of teachers indicate that the pedagogical changes they make are regular, so that the pedagogical change is high, the teacher's attitude must be changed and made into a good leader who develops skills to communicate with their students. This agrees with Miña et al. (2018) and Aguiar et al. (2016) highlighting that to develop this change in pedagogy, there is a need for trained and updated teachers who can respond to the demands they have 
on their professional performance, who are willing and committed to actively participate in the changes seeking to achieve self-improvement and improvement of educational quality.

In Table 2, 60\% of teachers express that the benefit of the decisions they make is regular according to the needs of their students, so they must improve the decision-making process by collecting data, generating alternatives and selecting a course of action. This agrees with Bustos and Vicuña (2016) and Gallardo et al. (2012) who consider that it is essential for the teacher to work on strengthening their assessment skills, specifically those of a formative nature, which allow a close monitoring of the student's teaching and learning process to achieve the goals and proposed objectives.

In Table 3, 80\% of teachers indicate that their participation in updating workshops and training is regular, teacher training must be permanent and continuous so that there can be a change in the way of teaching the teacher and student learning. This agrees with Nieva and Orietta (2016) and Hernández et al. (2018) who consider that teacher training has to be continuous and permanent for there to truly be a change in society. Teacher training is necessary for development and social transformation that require a change in which priority is given to the teacher as an active agent of learning transforming society.

In Table 4, 45\% of teachers indicate that the use of technology in their learning session for the achievement of competences is low, technology should be used in the training of both the teacher and the student using technological trends in education. Which agrees with Pedraza et al. (2013) and Buzón-García (2005) that teachers have to develop skills to incorporate these new technologies since the quality of student learning and teaching is largely related to teacher training.

In Table 5, $80 \%$ of teachers indicate that the strengthening of the teaching and learning process thanks to communication is high, the results indicate that teacher communication is the basis for learning and for the achievement of good relationships with the student. This agrees with Abraham et al. (2017) and Escobar (2015) who consider that communication in the relationship between the student and the teacher is of great importance to strengthen the teaching and learning processes in students. At the same time, dialogue develops freedom, personality, self-confidence and the expression of thought, forming autonomous people with abilities and skills to function in society. 


\section{ACKNOWLEDGMENT}

Special thanks to the National University of Cañete, the Research Group on Entrepreneurship and Innovation $\mathbf{C} @ \tilde{n}$ eteLab, its great professors, valuable students and collaborators for carrying out this scientific article throughout these years of study. Specially to Miss Diana Pamela

\section{REFERENCES}

Abraham, M., Donoso, P., \& Guzmán, I. (2017). Los Procesos de Cambios en los Saberes Pedagógicos de Alumnas y Alumnos de Pedagogía en Educación Básica. Paulo Freire, 1, 109. https://doi.org/10.25074/07195532.1.534

Aguiar, D., Capuano, A., Diez, M., Foures, G., \& Silin, I. (2016). Cambios y permanencias en las prácticas de enseñanza con TIC, Neuquén, Argentina. Ciencia, Docencia y Tecnología, 27(53), 315-341. https://dialnet.unirioja.es/servlet/ articulo? codigo $=5752772$

Bustos, E. S., \& Vicuña, S. D. (2016). Decision making and adaptation processes to climate change. Ambiente e Sociedade, 19(4), 215-234. https:/ / doi.org/10.1590/18094422ASOCEx0004V1942016

Buzón-García, O. (2005). La incorporación de plataformas virtuales a la enseñanza: una experiencia de formación on-line basada en competencias. RELATEC: Revista Latinoamericana de Tecnología Educativa, 4(1), 77-100. https://dialnet.unirioja.es/ servlet/articulo? codigo $=1303698$

Escobar, M. (2015). Influencia de la interacción alumno-docente en el proceso enseñanzaaprendizaje. PAAKAT: Revista de Tecnología y Sociedad, 8(5), 1-8. http:/ / www.udgvirtual. udg.mx/paakat/index.php/paakat/article/view/230/347

Gallardo, E. K., Gil, M. E., Gontreras, B., Evelyn, G. H., Lázaro, R. A., \& Ocaña, L. (2012). Toma de decisiones para la evaluación formativa: El proceso de planeación y determinación de sus mecanismos. Sinéctica, 39. http://www.scielo.org.mx/scielo. php?script=sci_arttext\&pid=S1665-109X2012000200011 
González, C., \& Cruzat, M. (2019). Innovación educativa: La experiencia de las carreras pedagógicas en la Universidad de Los Lagos, Chile. Educación, 28(55), 103-122. https://doi.org/10.18800/educacion.201902.005

Hernández, R. M., Orrego, R., \& Quiñones, S. (2018). Nuevas formas de aprender: La formación docente frente al uso de las TIC. Propósitos y Representaciones, 6(2), 671. https://doi.org/10.20511/pyr2018.v6n2.248

López, E., García, L. F., \& Martínez,J. E. (2019). La gestión directiva como potenciadora de la mejora del clima organizacional y la convivencia en las instituciones de educación media superior. RIDE Revista Iberoamericana Para La Investigación y El Desarrollo Educativo, 9(18), 792-812. https://doi.org/10.23913/ride.v9i18.471

Macanchí, M. L., Orozco, B. M., \& Campoverde, M. A. (2020). Innovación educativa, pedagógica y didáctica. Concepciones para la práctica en la educación superior. Revista Universidad y Sociedad, 12(1), 396-403. http://scielo.sld.cu/scielo. php?script=sci_arttext\&pid=\$2218-36202020000100396\&lng=es\&nrm=iso\&tlng= es

Martínez, D. Y., \& Ibarra A. R. (2017). La importancia de la innovación en la formación pedagógica. La Innovación y El Humanismo. Perspectiva Desde y Para La Educación Superior, 6(18). http://www.revistacoepesgto.mx/revistacoepes 18/la-importancia-de-lainnovacion-en-la-formacion-pedagogica

Medina, Y. (2019). Las innovaciones pedagógicas y su relación con la vicerrectorado de investigación. http://repositorio.unfv.edu.pe/bitstream/handle/UNFV/3677/ASTULLA MEDINA YTZIA - MAESTRIA.pdf? sequence=1 \&isAllowed=y

Mejía, M. (2018). La importancia de la internacionalización. Amec. https:// innovacioneducativa959245204.wordpress.com/2018/08/14/la-importancia-dela-innovacion-educativa/

Miña,L., ORelly, D., García, G., Pérez, Z., \& Moreno, L.E. (2018). Papel dela Pedagogía del cambio en la Educación de Postgrado. Revista Médica Electrónica, 40(2), 445-453. http://scielo.sld.cu/scielo.php?script=sci_arttext\&pid=S1684-18242018000200019 
Miranda, S. (2016). La gestión directiva: un concepto construido desde las comprensiones de los directivos docentes de las escuelas públicas bogotanas. RIDE Revista Iberoamericana Para La Investigación y El Desarrollo Educativo, 7(13). https://doi.org/10.23913/ride. v7i13.245

Nieva, J. A., \& Orietta, G. (2016). Una nueva mirada sobre la formación docente. Revista Universidad y Sociedad, 8(4), 14-21. http://scielo.sld.cu/scielo.php?script=sci_ arttext\&pid=S2218-36202016000400002

Pedraza, N., Farías, G., Lavín, J., \& Torres, A. (2013). Ict teaching skills in the areas of business and accounting an exploratory study in higher education. Perfiles Educativos, 35(139), 8-24. https://doi.org/10.1016/s0185-2698(13)71806-3

Reynoso, J. (2018). Un diagnóstico de la universidad mexicana en la obra El libro de la universidad imaginada. RIDE Revista Iberoamericana Para La Investigación y El Desarrollo Educativo, 9(18), 952-978. https://doi.org/10.23913/ride.v9i18.485

Rodríguez, E. (2018). El ejercicio de la función directiva en contextos complejos: su profesionalización. Perspectiva Educacional, 57(3), 131-152. https://doi. org/10.4151/07189729-vol.57-iss.3-art.775

Vergara, M., Galvo, G., Franco, M., Garavito, G., Londoño, S., Zapata, F., \& Camargo, M. (2004). Las necesidades de formación permanente del docente. Educación y Educadores, 7(7), 79-112. https://www.researchgate.net/ publication/28121400_Las_necesidades_de_formacion_permanente_del_docente 